\title{
A simple algorithm for the treatment of traumatic cardiac arrest
}

\author{
DJ Lockey*, RM Lyon, GE Davies \\ From London Trauma Conference 2012 \\ London, UK. 4-7 December 2012
}

\section{Background}

Major trauma is the leading causing of death in young adults across the globe. The mortality from traumatic cardiac arrest remains high but survival with good neurological outcome from cardiopulmonary arrest following major trauma has now been reported. Rapid, effective intervention is required to address potential reversible causes of traumatic cardiac arrest if the victim is to survive. There is no standard treatment algorithm for traumatic cardiac arrest. We present a simple algorithm to manage the major trauma patient in actual or near cardiac arrest.

\section{Methods}

We reviewed current pre-hospital clinical practice and the published literature on major trauma management. An algorithm was developed and used regularly by London's Air Ambulance pre-hospital physician/paramedic trauma team.

\section{Results}

The algorithm addresses the need treat potential reversible causes of traumatic cardiac arrest. This includes immediate resuscitative thoracotomy in cases of penetrating chest or abdominal trauma resulting in cardiac arrest, airway management, optimising oxygenation, reversal of hypovolaemia using intravenous/intraosseous fluid replacement and chest decompression to exclude tension pneumothorax.

\section{Conclusion}

A standard approach to traumatic cardiac arrest is feasible. Use of a treatment algorithm can rapidly, simultaneously address reversible causes of traumatic cardiac arrest and has the potential to save lives.

London's Air Ambulance, London, UK

(C) 2013 Lockey et al; licensee BioMed Central Ltd. This is an Open Access article distributed under the terms of the Creative Commons Attribution License (http://creativecommons.org/licenses/by/2.0), which permits unrestricted use, distribution, and reproduction in any medium, provided the original work is properly cited.
doi:10.1186/1757-7241-21-S1-S10

Cite this article as: Lockey et al:: A simple algorithm for the treatment of traumatic cardiac arrest. Scandinavian Journal of Trauma, Resuscitation and Emergency Medicine 2013 21(Suppl 1):S10.
Submit your next manuscript to BioMed Central and take full advantage of:

- Convenient online submission

- Thorough peer review

- No space constraints or color figure charges

- Immediate publication on acceptance

- Inclusion in PubMed, CAS, Scopus and Google Scholar

- Research which is freely available for redistribution 